ISSN 0258-7122

Bangladesh J. Agril. Res. 37(4): 677-682, December 2012

\title{
RESPONSE OF MUSTARD TO BORON FERTILIZATION
}

\author{
M. H. RASHID ${ }^{1}$, M. M. HASAN ${ }^{2}$, M. AHMED ${ }^{3}$, M. T. RAHMAN ${ }^{4}$, \\ K. A. M. M. RAHMAN ${ }^{5}$
}

\begin{abstract}
A field experiment was carried out in non-Calcareous Floodplain Soil of Spices Research Sub-Station, Lalmonirhat under AEZ 2 during the rabi season of 20072008 and 2008-09. The objectives were to evaluate the effect of boron on the yield of mustard and to screen out the suitable variety tested against different boron levels for maximizing yield. Three varieties of mustard viz., BARI Sharisha-11, 13, and 14 and 5 levels of boron (0, 0.5, 1.0, 1.5 and $2.0 \mathrm{~kg} / \mathrm{ha}$ ) along with a blanket dose of $\mathrm{N}_{120} \mathrm{P}_{35} \mathrm{~K}_{65} \mathrm{~S}_{20} \mathrm{Zn}_{3.0} \mathrm{~kg} / \mathrm{ha}$ were used in the study. Results revealed that BARI Sharisha-11 performed better with $1.5 \mathrm{~kg} \mathrm{~B} / \mathrm{ha}$ which produced 1.82 t/ha seed. However, from regression analysis, a positive but quadratic relationship was observed between seed yield and boron levels. The optimum dose of boron was appeared to be 1.7 and $1.6 \mathrm{~kg} \mathrm{~B} / \mathrm{ha}$ for Lalmonirhat during 2007-08 and 2008-09, respectively.
\end{abstract}

Keywords: Response of mustard, boron, yield.

\section{Introduction}

Mustard is the principal oilseed crop of Bangladesh that covers more than $60 \%$ of the total oil seed area (BBS, 2006). At present, the local production of edible oil meets only $25 \%$ of the country's requirement. The average yield of mustard in Bangladesh is only $700 \mathrm{~kg} / \mathrm{ha}$ (BBS, 2006), which is very low compared to other mustard growing countries of the world. They usually grow the local varieties, mainly Tori-7 with their own fertilizer management. Farmers generally apply lower amount of NPK and they do not apply boron fertilizer as a source of micronutrient to mustard. Due to intensive cultivation, the deficiency of the nutrient is reported to be very pronounced in some parts of the country particularly in the north western region. In the recent years, positive response of boron fertilization has been reported for many crops like chickpea, mungbean soybean, groundnut, mustard, cauliflower, tomato, papaya, maize, wheat, etc. Boron is very important in cell division and in pod and seed formation. Rate of water adsorption and carbohydrate transaction is restricted due to boron deficiency. Thus, boron fertilization is necessary for improvement of crop yield as well as nutritional quality.

\footnotetext{
${ }^{1}$ Scientific Officer, Soil Science Division, Bangladesh Agricultural Research Institute (BARI), Gazipur; ${ }^{2}$ Scientific Officer, Spices Research Centre, BARI, Bogra, ${ }^{3}$ Senior Scientific Officer, Spices Research Sub-station, BARI, Lalmonirhat, ${ }^{4}$ Senior Scientific Officer, RARS, BARI, Ishurdi and ${ }^{5}$ Scientific Officer, Biotechnology Division, BARI, Gazipur, Bangladesh.
} 
Mustard crop is very much responsive to boron application (Mengel and Kirkby, 1987). There are numerous reports on the positive response of mustard to B fertilization (Islam, 2005; Hossain et al., 1995 and Saha et al. 2003). There is a good scope to introduce high yielding varieties of mustard with proper management of fertilizer. This will help increase the present yield level of oilseed and thus will reduce the gap between present production and requirement. The response of newly released mustard varieties to boron application has not been observed yet. Considering the above perspectives, the present investigation was carried out to evaluate the effect of boron on the yield of mustard and to screen out the suitable variety (s) tested against different boron levels for maximizing yield

\section{Materials and Method}

Field experiments were conducted in non-Calcareous Floodplain Soil at the Spices Research Sub-Station, Lalmonirhat (AEZ-2) during the rabi season of 2007-2008. The nutrient status of initial soil has been presented in Table 1.

The experiment was laid out in randomized complete block design with three replications. It was a factorial experiment with 5 levels of $B(0,0.5,1.0,1.5$, and $2.0 \mathrm{~kg} / \mathrm{ha}$ ) and 3 varieties of mustard viz. BARI sharisha-11 (Brassica juncea), BARI Sharisha-13(Brassica napus), andBARI Sharisha-14(Brassica campestris).

Table 1. Chemical properties of the soil at the experimental field, (Lalmonirhat).

\begin{tabular}{|c|c|c|c|c|c|c|c|c|c|c|}
\hline \multirow[t]{2}{*}{ Item } & \multirow[t]{2}{*}{$\mathrm{pH}$} & \multirow{2}{*}{$\begin{array}{c}\text { OM } \\
\%\end{array}$} & \multirow[t]{2}{*}{ Total N \% } & $\mathrm{Ca}$ & $\mathrm{Mg}$ & K & $\mathrm{P}$ & S & $\mathrm{Zn}$ & B \\
\hline & & & & \multicolumn{3}{|c|}{$\mathrm{meq} / 100 \mathrm{~g}$} & \multicolumn{4}{|c|}{$\mu \mathrm{g} / \mathrm{g}$} \\
\hline Result & 5.1 & 0.8 & 0.04 & 14 & 0.5 & 0.1 & 11.1 & 10.2 & 1.8 & 0.1 \\
\hline \multicolumn{2}{|c|}{ Critical level } & - & 0.10 & 2.0 & 0.8 & 0.2 & 14 & 14 & 2.0 & 0.2 \\
\hline Interpretation & Acidic & Very Low & Very low & High & Low & Low & Low & Low & Low & Low \\
\hline
\end{tabular}

Fifteen different treatment combinations were constituted for verification. The unit plot size was $3 \mathrm{~m} \mathrm{x} 3 \mathrm{~m}$ and the seeds were sown in mid November for both the locations by maintaining $30 \mathrm{~cm}$ row to row distance apart. Boric acid was used as a source of boron. Five levels each of B $(0,0.5,1.0,1.5$, and 2.0 $\mathrm{kg} / \mathrm{ha}$ ) along with a blanket dose of other chemical fertilizers $\left(\mathrm{N}_{120} \mathrm{P}_{35} \mathrm{~K}_{65} \mathrm{~S}_{20} \mathrm{Zn}_{3}\right.$ $\mathrm{kg} / \mathrm{ha}$ ) were taken in the test. All P, K, S, Zn, B, and $1 / 2$ of $\mathrm{N}$ were applied at the time of final land preparation and remaining $1 / 2 \mathrm{~N}$ was top dressed prior to flowering. Irrigation and other intercultural management practices were done as and when necessary. The crop was harvested on 15 March and the necessary data on different parameters were recorded from 10 randomly selected plants. Then it was computed and analyzed statistically through MSTAT-C package. The analyzed data was adjusted with Least Significant Difference (LSD) test at $5 \%$ level. 


\section{Results and Discussion}

\section{Effect of variety}

The studied parameters like plant height, pods/plant, 1000-seed wt and seed yield were significantly highest with BARI Sharisha-11 (Table 2). The maximum number of pods/plant (110.1) were recorded in BARI Sharisha-11 followed by that in BARI Sharisha-14 and BARI Sharisha-13. Filled grains per pod was found highest in BARI Sharisha-13 and lowest in BARI Sharisha-11. Oil content varied significantly among the three varieties of which BARI Sarisha-14 contributed the highest content. The highest seed yield $\left(1.55 \mathrm{t} / \mathrm{ha}^{-1}\right)$ was recorded in BARI Sarisha-11 followed by that in BARI Sarisha-13 and BARI Sarisha-14 for both the study years. Patil et al. (1996) supported the result and stated that Brassica juncea (BARI Sharisha-11) exhibited significantly higher yield than Brassica campestries (BARI Sharisha-14).

Table 2. Mean effects of variety on the yield and yield contributing characters of mustard at SRSS, Lalmonirhat during 2007-08 and 2008-09.

\begin{tabular}{l|c|c|c|c|c|c|c}
\hline Variety & $\begin{array}{c}\text { Plant } \\
\text { height } \\
(\mathrm{cm})\end{array}$ & $\begin{array}{c}\text { Pods/ } \\
\text { plant }\end{array}$ & $\begin{array}{c}\text { Filled } \\
\text { grains/pod }\end{array}$ & $\begin{array}{c}\text { 1000-seed } \\
\text { wt (g) }\end{array}$ & $\begin{array}{c}\text { Oil } \\
\text { content } \\
(\%)\end{array}$ & \multicolumn{2}{|c}{$\begin{array}{c}\text { Seed yield } \\
\text { (t/ha })\end{array}$} \\
\hline BARI Sarisha-11 & $135.7 \mathrm{a}$ & $110.1 \mathrm{a}$ & $14.3 \mathrm{c}$ & $3.55 \mathrm{a}$ & 39.70 & $1.52 \mathrm{a}$ & $1.55 \mathrm{a}$ \\
BARI Sarisha-13 & $124.5 \mathrm{~b}$ & $71.8 \mathrm{c}$ & $26.8 \mathrm{a}$ & $3.48 \mathrm{~b}$ & 40.21 & $1.32 \mathrm{~b}$ & $1.39 \mathrm{~b}$ \\
BARI Sarisha-14 & $105.7 \mathrm{c}$ & $86.8 \mathrm{~b}$ & $25.3 \mathrm{~b}$ & $3.47 \mathrm{~b}$ & 41.62 & $1.18 \mathrm{c}$ & $1.37 \mathrm{~b}$ \\
\hline F test & $* *$ & $* *$ & $* *$ & $* *$ & $* *$ & $* *$ & $* *$ \\
CV (\%) & 4.0 & 5.3 & 6.32 & 1.3 & 0.84 & 6.13 & 6.2 \\
\hline
\end{tabular}

Figures in a column having same letter(s) do not differ significantly at $5 \%$ level by DMRT.

\section{Effect of boron}

In both the years, yield and yield contributing characters increased significantly with the increased rate of boron application up to $1.5 \mathrm{~kg} \mathrm{~B} / \mathrm{ha}$ (Table 3). Boron did not play significant effect on plant height and 1000-seed weight. The number of pods per plant increased significantly due to boron application and the effect was very pronounced among the studied characters. Malwear et al. (2001) found that stover yield significantly increased with the increment of boron levels. However, the highest number of pods per plant was recorded when $B_{1.5} \mathrm{~kg} / \mathrm{ha}$ 
was applied, which was higher over rest of the boron levels. Filled grains per pod was highest (24.62) with $1.5 \mathrm{~kg} / \mathrm{ha}$, which was identical to $2.0 \mathrm{~B} \mathrm{~kg} / \mathrm{ha}$. Subbaiah (1996) in his study suggested that boron deficiency could often increase the pollen abortion and leads to significant drop in seed production. Oil content (\%) was significantly increased due to increment of boron levels upto $1.5 \mathrm{~kg} \mathrm{~B} / \mathrm{ha}$. Malewar et al. (2001) obtained highest oil content at $1.5 \mathrm{~kg} \mathrm{~B} / \mathrm{ha}$ which supports the present findings. The highest seed yield (1.68 t/ha) was obtained with $1.5 \mathrm{~kg}$ $\mathrm{B} /$ ha which was significantly higher over rest of the boron levels. Sinha et al. (1991) and Sen et al. (2005) observed $1.5 \mathrm{~kg} \mathrm{~B} / \mathrm{ha}$ as the optimum dose for mustard cultivation.

Table 3. Mean effects of boron on the yield and yield contributing characters of mustard at SRSS, Lalmonirhat during 2007-08 and 2008-09.

\begin{tabular}{|c|c|c|c|c|c|c|c|}
\hline \multirow{2}{*}{$\begin{array}{c}\text { Boron } \\
\text { (kg/ha) }\end{array}$} & \multirow{2}{*}{$\begin{array}{l}\text { Plant } \\
\text { height } \\
(\mathrm{cm})\end{array}$} & \multirow{2}{*}{$\begin{array}{l}\text { Pods/ } \\
\text { plant }\end{array}$} & \multirow{2}{*}{$\begin{array}{c}\text { Filled } \\
\text { grains/ } \\
\text { pod }\end{array}$} & \multirow{2}{*}{$\begin{array}{l}1000- \\
\text { seed wt } \\
\text { (g) }\end{array}$} & \multirow{2}{*}{$\begin{array}{c}\text { Oil } \\
\text { content } \\
(\%)\end{array}$} & \multicolumn{2}{|c|}{ Seed yield (t/ha) } \\
\hline & & & & & & 2007-08 & 2008-09 \\
\hline 0 & 120.7 & $75.7 d$ & $17.5 \mathrm{c}$ & 3.49 & $39.95 b$ & $0.97 d$ & $0.92 \mathrm{~d}$ \\
\hline 0.5 & 120.9 & $82.8 \mathrm{c}$ & $21.2 \mathrm{~b}$ & 3.50 & $40.52 a$ & $1.24 \mathrm{c}$ & $1.34 \mathrm{c}$ \\
\hline 1.0 & 122.2 & $92.6 b$ & $22.8 \mathrm{ab}$ & 3.51 & $40.82 \mathrm{a}$ & $1.43 b$ & $1.59 \mathrm{~b}$ \\
\hline 1.5 & 123.5 & $100.0 \mathrm{a}$ & $24.6 a$ & 3.59 & $40.77 a$ & $1.54 \mathrm{a}$ & $1.68 \mathrm{a}$ \\
\hline 2.0 & 122.9 & $96.8 \mathrm{ab}$ & $24.4 \mathrm{a}$ & 3.50 & $40.49 a$ & $1.52 \mathrm{a}$ & $1.56 \mathrm{ab}$ \\
\hline F test & ns & $* *$ & $* *$ & ns & $* *$ & $* *$ & $* *$ \\
\hline CV (\%) & 4.0 & 5.3 & 6.32 & 1.3 & 0.84 & 6.13 & 6.2 \\
\hline
\end{tabular}

Figures in a column having same letter(s) do not differ significantly at 5\% level by DMRT.

\section{Interaction effects of variety and boron}

Of the studied parameters, the yield and number of filled grains per pod of mustard increased significantly due to interaction effect of variety and boron (Table 4). The highest seed yield (1.82 t/ha) was recorded in BARI Sarisha-11 with $1.5 \mathrm{~kg} \mathrm{~B} / \mathrm{ha}$, which was significantly higher over rest of the boron levels irrespective of varieties tested. Similar trend of results were observed in case of seed yield by Shen et al. (1998) and Khurana et al. (1998). 
Table 4. Interaction effect of variety and levels of boron on the yield and yield contributing characters of mustard at SRSS, Lalmonirhat during 2007-08 and 2008-09.

\begin{tabular}{|c|c|c|c|c|c|c|c|c|}
\hline \multicolumn{2}{|c|}{ Treatments } & \multirow{2}{*}{$\begin{array}{l}\text { Plant } \\
\text { height } \\
(\mathrm{cm})\end{array}$} & \multirow{2}{*}{$\begin{array}{l}\text { Pods } \\
\text { plant }\end{array}$} & \multirow{2}{*}{$\begin{array}{c}\text { Filled } \\
\text { grains } \\
\text { pod }\end{array}$} & \multirow{2}{*}{$\begin{array}{c}1000- \\
\text { seed } \\
\text { wt }(g)\end{array}$} & \multirow{2}{*}{$\begin{array}{c}\text { Oil } \\
\text { Content } \\
(\%)\end{array}$} & \multicolumn{2}{|c|}{$\begin{array}{c}\text { Seed yield } \\
(\mathrm{t} / \mathrm{ha})\end{array}$} \\
\hline Variety & $\begin{array}{c}\text { Boron } \\
\text { (kg/ha) }\end{array}$ & & & & & & 2007-08 & 2008-09 \\
\hline \multirow{5}{*}{$\begin{array}{c}\text { BARI } \\
\text { Sarisha-11 }\end{array}$} & 0 & 133.6 & 95.3 & $11.9 \mathrm{~g}$ & 3.55 & 39.2 & $1.01 \mathrm{~h}$ & $0.93 g$ \\
\hline & 0.5 & 134.0 & 102.3 & $13.5 \mathrm{fg}$ & 3.56 & 39.7 & 1.36de & 1.39def \\
\hline & 1.0 & 135.3 & 113.0 & $14.1 \mathrm{fg}$ & 3.56 & 39.9 & $1.68 \mathrm{~b}$ & $1.80 \mathrm{a}$ \\
\hline & 1.5 & 137.6 & 121.3 & $15.2 \mathrm{fg}$ & 3.56 & 40.0 & $1.78 \mathrm{a}$ & $1.82 \mathrm{a}$ \\
\hline & 2.0 & 137.6 & 118.3 & 16.6ef & 3.55 & 39.6 & $1.76 \mathrm{a}$ & $1.80 \mathrm{a}$ \\
\hline \multirow{5}{*}{$\begin{array}{c}\text { BARI } \\
\text { Sarisha-13 }\end{array}$} & 0 & 123.6 & 60.3 & 19.7de & 3.48 & 39.6 & 0.96hi & $0.91 \mathrm{~g}$ \\
\hline & 0.5 & 124.3 & 66.3 & $25.3 c$ & 3.47 & 40.2 & $1.23 f$ & $1.31 \mathrm{f}$ \\
\hline & 1.0 & 124.6 & 74.0 & 28.0abc & 3.51 & 40.7 & $1.41 d$ & $1.51 \mathrm{bcd}$ \\
\hline & 1.5 & 125.3 & 81.7 & $31.0 \mathrm{a}$ & 3.48 & 40.5 & $1.50 \mathrm{c}$ & $1.63 \mathrm{~b}$ \\
\hline & 2.0 & 124.5 & 76.0 & 30.0ab & 3.46 & 40.1 & $1.49 c$ & $1.61 \mathrm{bc}$ \\
\hline \multirow{5}{*}{$\begin{array}{c}\text { BARI } \\
\text { Sarisha-14 }\end{array}$} & 0 & 104.6 & 71.7 & 20.9d & 3.47 & 41.1 & $0.93 \mathrm{i}$ & $0.92 \mathrm{~g}$ \\
\hline & 0.5 & 104.3 & 80.0 & $24.7 c$ & 3.47 & 41.7 & $1.13 g$ & 1.33ef \\
\hline & 1.0 & 106.6 & 90.0 & $26.3 c$ & 3.47 & 41.8 & $1.21 \mathrm{f}$ & 1.46cde \\
\hline & 1.5 & 106.3 & 97.0 & 27.7abc & 3.45 & 41.8 & $1.33 \mathrm{e}$ & $1.58 \mathrm{bc}$ \\
\hline & 2.0 & 106.3 & 95.3 & $26.7 \mathrm{bc}$ & 3.49 & 41.7 & $1.31 \mathrm{e}$ & $1.56 \mathrm{bc}$ \\
\hline F test & & ns & ns & $* *$ & ns & ns & $* *$ & ns \\
\hline $\mathrm{CV} \%$ & & 4.0 & 5.3 & 6.3 & 1.3 & 0.84 & 6.1 & 6.2 \\
\hline
\end{tabular}

Figures in a column having same letter(s) do not differ significantly at 5\% level by DMRT.

\section{Response function}

A positive but quadratic relationship was observed between boron and yield of mustard regardless of varieties at both the years (Fig. 1 and 2). From the quadratic equation the optimum dose of boron was calculated to be 1.7 and 1.6 $\mathrm{kg} / \mathrm{ha}$ for Lalmonirhat during 2007-08 and 2008-09, respectively.
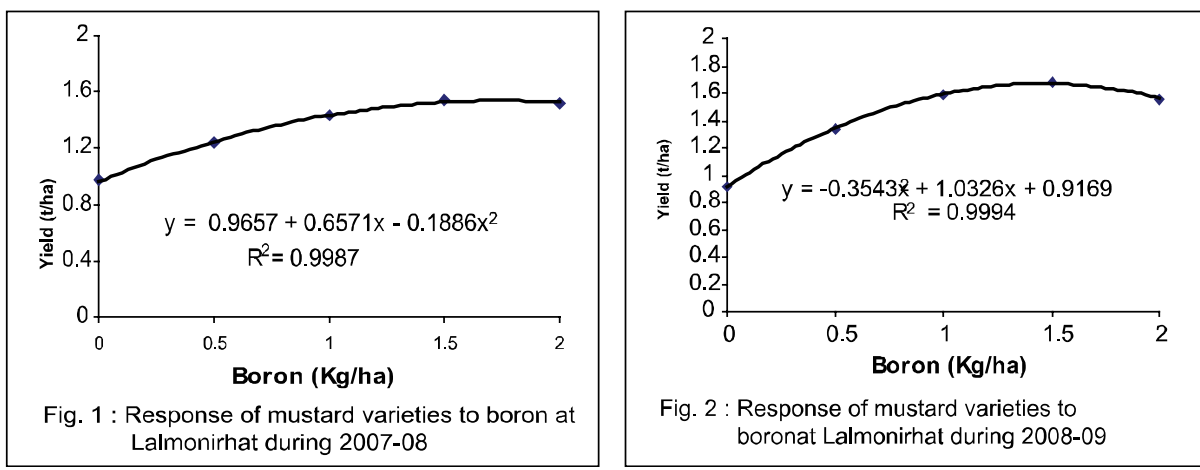

Fig. 2 : Response of mustard varieties to boronat Lalmonirhat during 2008-09 


\section{Conclusion}

It can be concluded from studies that $\mathrm{B}$ at the rate of $1.5 \mathrm{~kg} / \mathrm{ha}$ along with a blanket dose of $\mathrm{N}_{120} \mathrm{P}_{35} \mathrm{~K}_{65} \mathrm{~S}_{20} \mathrm{Zn}_{3} \mathrm{~kg} / \mathrm{ha}$ can be regarded as the best combination for all the varieties tested in the study area. BARI Sharisha- 11 was superior to other tested varieties. From the regression analysis, the optimum dose of boron was found to be 1.7 and $1.6 \mathrm{~kg} / \mathrm{ha}$ for Lalmonirhat during 2007-08 and 2008-09, respectively.

\section{References}

BBS. 2006. The Year Book of Agricultural Statistics of Bangladesh, Statistics Division, Ministry of Planning, Dhaka, Bangladesh.

Hossain, M. A., M. Jahiruddin and F. Khatun. 1995. Response of wheat and mustard to manganese, zinc and boron in Calcareous Soil. Bangladesh J. Crop Sci. 6(1\&2): 5156.

Islam, M. B. 2005. Requirement of boron for mustard, wheat, and chickpea based rice cropping patterns. Ph. D. Dissertation, Department of Soil Sci. Bangladesh Agricultural University, Mymensingh.

Khurana, M.P.S., V.K. Nayyan and R.L. Bansal. 1998. Direct and residual effects of S and $\mathrm{Zn}$ on yield and their uptake in an Indian mustard (B. Juncea c.) Maize (Zea mays) cropping syalem. Acta Agronomica Hungarica 46:32-34.

Malewar, G. U., S. D. Kale., S. L. Walkar and S. Ismail, 2001. J. Indian Soil Sci. 49(4): 763-765.

Mengel, K. and E. A. Kirkby. 1987. Principle of plant nutrition. International Potash Institute, Switzerland.

Patil, B.N., K.C. Lakkineni and S.C. Bhargava. 1996. Seed yield and yield contributing characters as influenced by $\mathrm{N}$ supply in rape seed mustard. J.Agron. Crop Sci. 177:197-207.

Saha, P.K., M. A. Saleque., S. K. Zaman and N. J. Bhuiyan. 2003. Response of mustard to S, Zn, and B in Calcareous Soil. Bangladesh J. Agril. Res. 28(4): 633-636.

Sen, R. and A. T. M. 2005. Effect of boron on yield and yield component of mustard. Bangladesh J. Agric. Env. 1(1): 65-68.

Sinha, R. B., R. Sakal., A. P. Singh and N. S. Bhogal. 1991. Response of some field crops to boron application in Calcareous Soil. J. Indian. Soc. Soil Sci. 39(1):118-122.

Shen, K., Z. G. Shen and Q. Y. Hung, 1998. A study of boron nutrition and seed setting in rape (B. napus). Acta Agronomic Sinica 19: 539-545.

Subbaiah, G. and B.N. Mittra. 1996. Effect of foliar spray of micronutrients on the yield and oil content of Indian mustard (B. juncea). Indian J. Agron. 41:95-97. 